Леся ОВЧІЕВА

\title{
ЛЮБОВ ЛІНИЦЬКА - ПЕРША ВИКОНАВИЦЯ ГОЛОВНИХ ЖІНОЧИХ РОЛЕЙ У П'ССАХ В. ВИННИЧЕНКА «БРЕХНЯ» І «НАТУСЬ»
}

У статті здійснено спробу охарактеризувати значення перших сиенічних постановок модернових n'єс В. Винниченка «Брехня» $i$ «Натусь», а також висвітлити акторське втілення головних жіночих ролей у зазначених виставах високоталановитою артисткою Любов'ю Павлівною Ліницькою.

Ключові слова: модернізм, неореалізм, режисерська інтерпретачія п'єси, акторська гра, сценічний образ.

В статье предпринята попытка определить значение первых сиенических постановок модернистских пьес В. Винниченко «Брехня» $и$ «Натусь», а также охарактеризовать актерское воплощение главных женских ролей в названных спектаклях высокоталантливой артисткой Любовью Павловной Линицкой.

Ключевые слова: модернизм, неореализм, режиссерская интерпретация пьесы, актерская игра, сиенический образ.

The article attempts to characterize the significance of the first stage productions of modern pieces by $V$. Vynnychenko «Lies» and "Natus», as well as highlight the actors' embodiment of the main female roles in the above-mentioned performances by a highly talented artist Lyubov Pavlovna Linitskaya.

Key words: modernism, neorealism, director's interpretation of the play, acting, scenic image.

Питання поетики неповторної цілісності драматургічного письма В. Винниченка багато років залишалось мало вивченим, наступні покоління українців майже нічого не знали ні про особу великого письменника, ні про значущість його творінь у літературі, а тим більше у театрі. Лише з часу незалежності України маємо значні спроби у відкритті мистецького світу багатолітнього вигнанця. Це праці Л. Мороз «Сто рівноцінних правд» (1994), О. Гнідан, Л. Дем'янівської «Володимир Винниченко: Життя. Діяльність. Творчість» (1996), В. Панченка «Будинок з химерами» (1998), В. Гуменюка «Сила краси» (2001) та інші. Хоч мало дослідженими залишаються проблеми сценічного втілення його драматичних творів, праці над цією драматургією режисерів та акторів - I. Мар'яненка, Леся Курбаса, Г. Юри, Ф. Левицького, М. Крушельницького, Л. Ліницької, П. Самійленко, тобто того мистецького покоління, що закладало основи новітнього театру. У своєму дослідженні сучасний театрознавець Г. Веселовська правильно зазначає, що «принциповий поворот вітчизняної сцени від традиційного фольклорно-етнографічного шляху розвитку до духовних шукань у сфері модерністського переосмислення театральної дійсності - припадає на 1910-ті роки» $[1,97]$. Причому цей поворот був закономірним і поступовим.

Вплив мистецьких течій європейського мистецтва доби модернізму на творчу манеру В. Винниченка найвиразніше визначила Лариса Мороз, заявивши, що в драматурга «риси поетики таких різних (а в чомусь і протилежних) напрямів, як натуралізм, реалізм, символізм, експресіонізм, поєднані в такому сплаві, що не виникає враження еклектичності; вони виростають із прагнення митця осягнути сутність особистості в цілому, не "вириваючи" з неї окремі частини названих вище опозицій» $[2,20]$.

Ім'я Володимира Винниченка, яке на початку $\mathrm{XX}$ століття здобуло фантастичну популярність, пізніше, за його політичну діяльність, більшовицькими партократами було «безжально, із жорстоким ідеологічним азартом викреслене майже на сімдесят років з нашого духовного спадку, паплюжене і замовчуване» [3, 92]. Так у передмові 3. Мороза до видання «Прошлое украинского театра» можна прочитати: «В репертуарі буржу- 
азного театру (в трупах Колесниченка, Захарченка та ін.) з'являлися ренегатські п'єси махрового націоналіста і декадента В. Винниченка — “Дисгармонія", “Базар", “Брехня"» [4, 24]. Це типове висловлювання автора, бо відомі авторитетні дослідники - С. Дурилін, В. Василько, П. Тернюк у своїх працях змушені були постійно наголошувати, що М. Заньковецька, П. Саксаганський та М. Садовський «принципово відкидали» п'єси Винниченка. Навіть I. Мар'яненко, начебто виправдовуючись, писав: «Слід проте відзначити, що не маючи змоги розібратись в хаосі реакційних течій того часу (андреєвщина, арцибашевщина, винниченківщина тощо) <..> ми, українські актори, в шуканнях нового робили ті ж помилки, що й робили російські театри, де чим раз більше завойовувала собі місце декаденська драматургія; отже, деяке місце зайняла вона і в нас» $[5,148]$.

Та насправді з драматургів нової хвилі найрепертуарнішим був В. Винниченко, який, за словами С. Єфремова, «сам мучився від нерозгаданих загадок, які ставило йому життя; жагуче добивався правди, допитливо розплутував “дисгармоніï” між сущим і тим, що повинно бути». Його п’єси ставали художньою лабораторією театру, «де логічно і послідовно випробувалися художні експерименти нової моралі, шлюбу і сім’ 1 , рівноправності чоловіка і жінки, стосунків між статями, співвідношення у поведінці людини свідомого й інстинктивного, виправдання вчинків метою розкриття психологічних таємниць творчості, ролі сім’ї в житті і творчості митця та ін.» $[6,187]$.

Ю. Смолич відзначав, що своєю психологічністю драматургія В. Винниченка вирізнялась i3 тодішнього всього загалу української соціально-побутової драми. Драматург «силою таланту свого, оригінальною мистецькою манерою посів місце “духозбудника" нової для українського театру культури» $[7,96]$. Більше того, своєю драматургією В. Винниченко виступив справжнім новатором, у ній виявлялися психологічна вишуканість образів, моральна парадоксальність, майстерність інтриги та своєрідність жанрово-стильової поетики, які захоплювали не лише українських глядачів, але й театральну публіку Берліна, Відня, Петербурга, Парижа і Рима. Дослідниця творчості В. Винниченка у діаспорі Л. Онишкевич стверджує, що драматург «випередив західноєвропейську літературу на три десятки років тим, що перший увів екзистенціалізм у західну драму. Він зумів передбачити, передчути і відмітити ситуацію вагань i вільного вибору, які стали щораз гострішими проблемами для людини XX століття» $[8,204]$.
Постановку «Брехні» В. Винниченка вперше здійснив у Київському театрі М. Садовського відомий митець, але режисер-початківець I. Мар'яненко, прем'єра вистави відбулася 20 січня 1911 року. Дослідник поетики драматургії В. Винниченка мистецтвознавець В. Гуменюк зауважує, що «п’єса “Брехня” належить до найбільш загадкових творів драматурга. Ця загадковість $є$ передусім його прикметною стильовою рисою, яка засвідчує суттєвість в поетиці автора стихії символізму. Нерозгаданість внутрішнього світу головної героїні Наталії Павлівни вражаюче прилучає нас до гострого й тривожного відчуття одвічних таємниць буття. Символіка жертви, <..> приймаючи образний лад, надає особливої (цілком віддаленої від публіцистичної однозначності) переконливості художньому осягненню суспільних проблем, коло яких означається опозицією понять правди - брехні» [9, 153].

Режисер I. Мар'яненко розумів, що у п'єсі «Брехня» автор не мав на увазі виразити апологію брехні як такої і не зумів ідею брехні виділити в ім'я правди, радше у творі має місце «брехня во спасіння». Адже смерть головної героїні позбавляє ближніх від важких страждань (цю думку висловлює один із претендентів на кохання Наталіі Павлівни, компаньйон іiі чоловіка Іван Стратонович - «краще смерть, ніж ганьба»). Проте більшість критиків п'єси залишалися такими, що не визначали головної проблеми твору, хоч міркування драматурга схвилювали. Мистецтвознавець О. Кисіль, сучасник В. Винниченка, зауважував: «Автор не нав'язує тут конечних висновків, але ставить питання оригінально і яскраво» $[10,136]$.

I. Мар'яненко як режисер зобов'язаний був визначитись конкретно, про що він сценічно втілюватиме цей твір. Його як інтерпретатора «Брехні» захоплювало своєрідне поєднання в п’єсі «актуальної моральної проблематики 3 їі філософським звучанням - що є істина? На думку режисера - це питання було і залишається найголовнішим, над яким б'ється людський розум, бажаючи пізнати мету і смисл існування людини і всього світу, що її оточує» $[6,189]$.

У режисерській творчості I. Мар'яненко намагався дбайливо використовувати ознаки сценічного реалізму з обережним уведенням символістської умовності. Завдання постановки режисер сформулював - дослідити проблему істини у світі та сімейних стосунках і засудити роль брехні у житті людей та їхній діяльності. Узагальнюючи свідчення рецензентів вистави, доходимо висновку, що найвиразніше ідея режисера доносилась до 
глядачів саме трактуванням ролі Наталії Павлівни артисткою Л. Ліницькою, героїня якої йде на компроміс зі своєю совістю і утворює цілу апологію брехні, де «істина є постаріла брехня», тому всяка брехня з часом може стати істиною. Усвідомивши принципове виправдання брехні, Наталія Павлівна застосовує цей принцип у реальне життя, використовуючи брехню як свою зброю для вибудовування стосунків між близькими людьми. Узаконюючи брехню, вона переконує своїх партнерів: «Якщо знаєш, що не для себе брешеш, а для того, кому брешеш, то се зовсім не важко, треба тільки, щоб ся брехня давала радість». При підготовці актрисою сценічного образу їй слід було врахувати ще одну авторську особливість: у багатьох випадках у п’єсі брехливість $є$ суттю жіночності, адже героїня мало не знічев'я обманює буквально всіх, навіть найкращих і найщиріших із тих, кому вона симпатизує. Дехто з дослідників стверджує, що для Винниченка у названій п’єсі поняття жінка і брехня синонімічні, а гріховна ця брехня чи вона «во спасение» - хай висловлюють своє розуміння інші.

Зрозуміло, що нова психологічна драма вимагала і нових методів сценічного втілення, тобто вимагала занадто обережного і глибокого ставлення артистів, аби не вдатися до чужого, не притаманного їй і вельми шкідливого мелодраматичного тону. Даючи поради постановникові щодо сценічного втілення «Брехні», мистецтвознавець М. Вороний наставляв: «Загальний ансамбль в деталях і суцільно характерна до дрібниць обстановка сцени вимагають найпильнішої уваги досвідченого, інтелігентного режисера» $[11,190]$.

Театрознавець П. Кравчук зауважує, що I. Мар'яненко добре усвідомлював, що романтичні і натуралістичні засоби сценічного втілення п'єси «Брехня» тут будуть загрубі та поверхові. «У роботі з акторами зовнішня інтрига й побут залишилися побіжними. Режисера цікавили потайні порухи душі персонажів, боротьба понадсвідомих і понадсмислових сил. Символічно-психологічні засоби, якими орудував у роботі над п'єсою постановник, були зовсім не звичними і часто не зрозумілими для більшості виконавців» $[6,190]$.

У непростій роботі акторів у новій виставі не всі скористалися добрими рекомендаціями теоретика і практика театральної справи М. Вороного, який писав: «Очевидно, схопити таку роль в стані першого зворушення, спонтастично неможливо, тут потрібна делікатна секція душі, яку могла доконати лише глибока аналітична думка, виплекана на грунті значного естетичного досвіду і в сфері широкого європейського погляду» $[11,368]$.
Але новий актор для модерного репертуару 3 глибоким психологічним змістом тільки-тільки формувався, і потрібен був певний час для його виховання. А виставу слід було грати вже тепер. Розповідають, що Винниченко, який був присутнім на прем'єрі інкогніто, не вдовольнився повністю сценічним втіленням свого твору. Адже сценічна версія «Брехні» не мала рівноцінного звучання 3 літературним твором. Головною причиною у цьому була непідготовленість київських митців до сприйняття і відтворення нової драматургічної стилістики. Окремі виконавці грали щиро, соковито, навіть з певними ефектами, але грали як у звичайній побутовій п'єсі. Мали успіх у глядачів Л. Ліницька у ролі Наталії Павлівни, С. Паньківський - Андрія Карповича.

Важливими сценічними епізодами для режисера були сцени двох вечірок у виставі, їхнє режисерське протиставлення. Перша (кінець першої діiі) 3 приводу приїзду батька Андрія Карповича, де радісно-пісенна атмосфера, у центрі якої щиро та емоційно-весело діяла Наталія - Ліницька. Друга - бенкет під фінал вистави, з причини завершення чоловіком і його компаньйоном роботи над створенням чудо-мотора. Тут Наталія Павлівна-Ліницька - в стані великих душевних терзань і внутрішньої стурбованості 3 пошуками виходу із подальшої нестерпної ситуації. Видно, що цьому персонажеві режисер надавав провідних особливостей, зокрема ії̈ пишномовним тирадам, що виособлювали іiї глибоко психологічний характер, численні підтексти у мові героїні вимальовували iї внутрішній світ. Навіть якщо всі персонажі мають виразні індивідуальності (люблячий i довірливий чоловік Андрій Карпович, його колега - невгамовний ревнивець Іван Стратонович i темпераментний поет-коханець, за визначенням самої Наталії Павлівної — «вогник» Антось), але передусім вони діяли на розкриття образу головної героїні.

У такому багатогранному ансамблі Л. Ліницька спромоглася відтворити образ людини 3 особливою співчутливістю, відвертою чуйністю і непересічною людяністю. Особливо це сприймалося у сцені ставлення до батька Андрія Карповича, цього гнобленого життям селянина, який, проте, не втрачає віру за всіх складнощів ситуацій. Адресовані героїнею слова звучали надзвичайно емоційно, молитовно: «...мені хотілось стати на коліна перед його батьком, обмити його ноги й витерти їх своїм волоссям». Можливо, в цей момент відбувався не вигаданий збіг - героїня-артистка згадувала власного не так давно померлого батька 
(Л. Ліницька декілька років тому поховала свого батька, який, як відомо, був для неї найріднішою людиною i найщирішим порадником-другом). Мабуть, саме внаслідок сприйняття цього епізоду рецензент газети «Рада» А. Вечерницький писав, що в «першій дії псував враження мелодраматичний тон, взятий артисткою» [12]. Можливо, тут стався неприпустимий випадок накладання особистої долі артистки на сценічну ситуацію.

Виконавиця ролі Наталії Павлівни дуже чітко визначала завдання і результати проведення сценічних діалогів з кожним персонажем. У сценах 3 Тосем Ліницька вела напружений і темпераментний діалог, коли героїні ледве вдавалося різкими змінами настроєвих відтінків заспокоїти ревнивість поета до ії ж чоловіка. 3 компаньйоном Андрія Карповича, «людиною-хмарою» Іваном Стратоновичем велася тонка любовна гра, під час якої Ліницька-Наталія переконувала партнера у щирому до нього коханні. 3 почуттям чуйності й людяності героїня поводиться зі своїм законним чоловіком Андрієм Карповичем, вона не може його ображати, потрібно показати дбайливе збереження сімейного затишку й домашнього ладу. Але жоден 3 цих близьких їй чоловіків не може зрозуміти цю жінку, тому вона існує в атмосфері душевної самотності. Прояви безмежної людяності та надзвичайної чуйності Наталією-Ліницькою як до самої себе, так і до людей близького оточення з метою їхнього заспокоєння, урівноваження та успішного здійснення їхніх планів, героїня, як їй здається, може втілити лише за допомогою «брехні», але, як наслідок, щоб у фіналі ця брехня не розкрилася, вона змушена накласти на себе руки. Цю фінальну сцену, за оцінкою рецензентів, Ліницька проводила 3 величезною переконливістю. Критик А. Вечерницький підсумовував: «Зате чудово пройшла в артистки сцена "розпродажі душі i серця", коли вона перед самогубством в третій дії шепче кожному з любовників солодке словечко, а потім всіх їх цілує. Це шедевр артистизму, i тим дужче він виділявся, тим більше приковував до себе увагу на сірому одноманітному фоні загального виконання всіма партнерами. Чи так, як автор, зрозуміла д-ка Ліницька свою роль, ми про те не будемо говорити, бо в усякому разі артистка дала мистецький образ, який лишає сильне враження» [12].

Рецезент журналу «Українська хата» П. Богацький (пс. Alienus), який активно підтримував модернові мистецькі тенденції, залишив своєю рецензією захоплюючі враження від гри Л. Ліницької, яка «виконала свою роль добре, з потріб- ною нюансіровкою (підкреслення наше. - Л. О.) і повним розумінням ролі» $[13,187]$. Далі критик розшифровував уміння і здатність виконавиці до роботи у новітній драматургії: «Багата душа артистки вмістила душу Наталії Павлівни, а техніка розроблена й широка спасла ії од можливостей запутатись в складних переживаннях. I всюди, де приходилось їй, наприклад, двоїтися, вона зробила це артистично» $[13,187]$. Л. Ліницька працювала у рамках вимог до нового артиста, iї слова були щирими і зрозумілими як для партнерів, так і для присутніх у залі, і не лише слова, а й умотивовані пластичні рухи, погляди й дикція: «Слова ще не все говорять. Багато більше говорить пластика. А вкупі вони дають можливість глядачам розгадати такі тонкі, такі складні душевні переживання, які ми ми бачимо в Наталії Павлівни продовж довгої муки в сітці, яку сама сплела» $[13,187]$.

Більшість оцінювачів сценічного прочитання нової п'єси В. Винниченка стримано відгукувались про постановку, але про працю Ліницької у виставі, як бачимо, висловлювалися дуже схвально. А взагалі висновок був маловтішний, бо зауважували, що частина артистів не зрозуміли цієї «п'єси настрою, не визначились 3 своїм завданням». Правда, критика позитивно оцінила ще виконання ролі Андрія Карповича актором С. Паньківським, який у цьому образі був багатогранною особистістю - i коханим чоловіком Наталії, i українським інженером, і кожному друг, і хвора людина; був усім, чого вимагали обставини, щоб дати розкритися коханій дружині. «Провідною характерною рисою персонажа було бути “начальником в руках Наталії Павлівни”» [13, 187]. 3 іншими партнерами Ліницькій, і насамперед 3 виконавцем ролі студента Тося, не пощастило. В автора цей персонаж - людина 3 гарячим, великим серцем, знервована, з особливим волевиявленням. Поет-неврастенік, однак роль не зовсім вдалася I. Мар'яненкові, акторові, вихованому на старій школі, школі історично-героїчних ролей. Хоч актор і розумів сутність складної ролі поета, у якого сильні бажання, виразні заяви протесту, але самого протесту не було, бо людина він слабка i безвольна. Мабуть, не підходила акторові ця роль за особливістю власного темпераменту. Адже він звик творити в стихії палкого, рухливого, могутньо-красивого стану. Він був імпозантний в усіх ролях, де цього вимагалось, але роль поета-мрійника, слабодухого і безвольного неврастеніка, не вдалася. Адже боротьба Тося з «брехнею» Наталії Павлівни виявлялася лише в заявах «не хочу», «не можу», хоч це для вистави й було потрібним, «бо 
тоді незрозумілими і неможливими стають вчинки Наталії Павлівни, та й сама “брехня” не може царювати серед тих, хто їй не покоряється» $[13,187]$.

Мало переконливим і слабким партнером для Л. Ліницької був артист О. Корольчук у ролі Івана Стратоновича, хоч актор цей славився виконанням ролей в історичних і побутових п'єсах. Однак у цій виставі, в ролі одного із коханців Наталії Павлівни, він більше нагадував мелодраматичного злочинця та демонічного ревнивця.

Та все ж першість за глибиною перевтілення й донесення авторських сентенцій належала Л. Ліницькій. I тут, хочемо того чи ні, а доводиться схилятися до міркувань незалежного майстра критичної думки Всеволода Чаговця, який вже через два дні після прем'єри писав: «Для ролі Наталі потрібна велика артистична сила і слід сказати, що Ліницька здолала іï повністю. ІЇ̈ героїня наповнена благородною внутрішньою чистотою, тією чистотою, яку не можуть запачкати недосконалі людські стосунки, що породжують культуру брехні... Брехати і залишатися духовно прекрасною - це потрібно було зробити і це зроблено д-кою Ліницькою $з$ великим надхненним мистецтвом» [14].

Очевидці згадують, що через чотири роки у поновленій виставі «Брехня» роль Тося виконував Лесь Курбас (запрошений у театр на місце вибулого I. Мар'яненка), саме він був тим переконливим «вогником», як часто його називала Наталія Павлівна. Але Л. Ліницькій не довелося грати у цій виставі (вона вийшла 3 театру М. Садовського) $з$ талановитим виконавцем ролі поета й запального коханця.

Перша постановка «Брехні» у театрі М. Садовського громадськість і критика сприйняли неоднозначно. А. Вечерницький писав, що «старались всі, але 3 цього старання не в кожного артиста і не скрізь вийшло щось путнє» [15]. Найбільше претензій до акторського виконання мав тодішній практик і теоретик театрального мистецтва М. Вороний: «Актор борсається, мучиться i, нарешті махнувши рукою, грає як звик, по старих трафаретах, мабуть сам почуваючи власну нікчемність $<\ldots>$ і замість перетонченої і складної натури Наталії Павлівни глядачі бачили Пракседу 3 "Помсти гуцула", а замість “живого символу", ірреальної постаті Івана Стратоновича сновигав по сцені Апраш з “Циганки Ази”! Не помогли ні “нутро”, ні “досвід”» $[11,72]$.

М. Вороний майже єдиний, хто не був захоплений постановкою «Брехні», але були у нього i серйозні опоненти. Так, О. Кузьминський (пс. А. Вечерницький) доходив висновку: «Чи так, як автор, зрозуміла д-ка Ліницька свою роль, ми про те не будемо говорити, бо в усякому разі артистка дала мистецький образ, який лишає сильне враження. У всякому разі нове вікно прорубане, і тим, хто коло цього попрацював, - велика дяка» [12].

У тому, звичайно, велика повага до таланту Любові Ліницької. Її Наталія Павлівна - наче жмут пристрасті між трьох «закоханих» у неї чоловіків. Вона як могла викручувалась між ними, а тому, підкорена ними, як здобич, що не бачить порятунку й знесилена, свідомо йшла жертовно до трагічного фіналу. Драматична вина героїні Л. Ліницької була в тому, що до кінця вірила, ніби дати щастя близьким людям можна й брехнею. Адже іiі життєвою заповіддю було переконання: «Людям зовсім не треба правди чи брехні, їм треба щастя, щастя, спокою. Коли брехня може це дати - слава брехні! Слава».

Підбиваючи підсумки театрального сезону театру М. Садовського за 1911/1912 роки, той самий О. Кузьминський назвав «Брехню» найоригінальнішою виставою сезону і зауважив, що «постановкою "Брехні” уперше розбито могутню фортецю старої української мелодрами і показано стежку для зближення українського театру з світовим» [16]. Павло Богацький, театральний оглядач «Української хати», роблячи окремі застереження деяким виконавцям «Брехні», найбільше висловлював задоволення грою першовиконавиці ролі Наталії Павлівни, однією з кращих українських актрис - Л. Ліницькою і в цілому високо оцінював постановку: «Український театр вперше давав матеріал інтересний і новий для думки, для чуття, вперше вабив публіку, нашу байдужу і холодну до всього публіку, до себе оригінальною, серйозною і цікавою драмою. Театр вдарив по нерву сучасності, торкнув болюче питання інтелігенції <..> 3 часу постановки "Брехні" ми можемо рахувати нову еру в історії нашого театру» $[13,187]$.

Сьогодні слід зауважити, що учасники першопостановки «Брехні», вочевидь, були свідомі в оцінці вистави, розуміючи ії здобутки, а разом i прорахунки, тому робота над вдосконаленням спектаклю, навіть після прем'єри, не припинялась, відпрацьовувались окремі епізоди. Про це свідчать рецензії оглядача газети «Киевский театральный курьер»: перша -7 лютого, друга 16 квітня 1911 року. У рецензії за 7 лютого вказуються певні недопрацювання у всій виставі й, зокрема, у грі Л. Ліницької: «Д-ці Ліницькій вдається змалювати виразний образ цієї жінки артистки на сцені < . .> але не вийшов у виконавиці порив, коли вона кидається за листами до Івана 
Стратоновича. Тут потрібно було більше експресії та безпощадності». Та вже у рецензії від 16 квітня, тобто майже через три місяці, немає жодного зауваження, сама лише похвала: «Центр цікавості виконання - д-ка Ліницька. Лукавство, кокетування, внутрішні муки сумління, сильні пориви почуття у акторському виконанні захоплюють глядачів. Задум автора артистка розкрила вірно i уміло відтворила його у своїй надхненній грі. Знаменито пройшла сцена оп'яніння у третій дії».

Однією $з$ особливостей сценічної творчості Л. Ліницької було те, що серйозну акторську роботу артистка берегла не сезон, не рік, а цілими десятиліттями. Так було з образом Наталії Павлівни. Вже працюючи навіть в іншій трупі, вона цю роль оберігала й зміцнювала, не боялась у ній виступати в Одесі, де колись вона не один раз складала творчий іспит своєю грою. Після показу «Брехні» у 1915 році одесити були у захваті як від вистави, так і від гри Ліницької-Наталії Павлівни: «Панегіристкою святої брехні автор зробив жінку, дружину інженера Наталію Павлівну. Вчора відтворений грою д-ки Ліницької цей образ хвилював і захоплював. Так були егоїстичні та жорстокі всі, хто зібрався навколо принадливої брехухи, недалекі правдолюбці, а симпатії глядачів були на боці цієї затравленої жінки, яка тільки одного хотіла - дати щастя людям, які ії оточують, хоча б навіть і ціною обману» [17].

Зі свого боку слід констатувати, що за сценічне втілення «Брехні», цієї глибокопсихологічної і багатошарової п'єси, мусив би взятися новітній режисер, якого на Україні ще не було. Новий актор тоді щойно почав формуватися, і потрібен був певний час для його виховання (принаймні школа Леся Курбаса). Але сміливість, наполегливість і певне відчуття сучасності I. Мар'яненка та глибоко майстерна й продумана гра Л. Ліницької робили неспинні кроки в театральну сучасність. Тандем драматург-режисер-актриса привідкривали завісу українського театрального модернізму.

Хоч М.К. Садовський не докладав ні творчих, ні фінансових зусиль до сценічного втілення у своєму театрі «Брехні» (щоправда, багато критиків і глядачів шкодували - чому б йому не грати роль Івана Стратоновича, адже вистава, за їхніми сподіваннями, набагато б виграла), але й не забороняв постановок творів Винниченка, i вже через два роки після постановки «Брехні» колектив випускає одну за одною винниченківські прем'єри - 12 жовтня 1913 р. «Натусь» 7 листопада цього ж року «Молоду кров», яку I. Мар'яненко навіть обрав для свого бенефісу. Любов Ліницька була зайнята лише у виставі «Натусь».
У ті роки В. Винниченка турбували питання ролі сім’ї в тогочасному житті людей, що присвячували себе серйозній науково-творчій діяльності. Це знайшло відтворення у його так званих сімейних п’єсах «Чорна Пантера і Білий Медвідь» та «Натусь». У першій — гине цілеспрямований та сильний духом художник Корній, коли не зважає на вимоги, що ставить перед ним сім'я: продати свою картину й закупити ліки для порятунку хворого сина. Але й герой «Натуся», молодий талановитий вчений Роман Возій губить свій хист через надмірну любов до сина, через яку він мусить зректися особистого щастя і наукової кар'єри. За трактуванням драматурга, в обох п'єсах він дивиться на сімейну проблему песимістично: через родинно-побутові кайдани видатні творчі особистості гинуть як самі для себе, так і для суспільства.

Перебуваючи під впливом нових модерністських течій у мистецтві та керуючись ними, В. Винниченко у своій новій п'єсі цілком спрямовує увагу на людину та іiї особисті проблеми, на індивідуальність персонажів у контексті загального суспільного розвитку. Як точно про це наголошувала Лариса Залеська-Онишкевич (США), у творах «реальність змішалась з ілюзією, хоч усе ж таки герої шукають свою правду чи шлях до неї» $[18,9]$. Природу конфлікту драматург переакцентовує на внутрішню дію персонажів, у якій центром драматизму стає духовне життя героїв, їхній внутрішній світ.

Модерні драми В. Винниченка відкрили й підняли на високий рівень жанр психологічної сімейної драми. За поетикою та стилістичними ознаками п’єса «Натусь» начебто подібна до «Брехні», але за літературно-художнім рівнем, за силою драматизму конфлікту вона поступалася попередній. Драматична дія в «Натусеві» базувалася на водевільних засадах, і це позбавляло твір внутрішнього драматизму. Тогочасний знавець і теоретик драми I. Стешенко, рецензуючи нову п'єсу В. Винниченка у журналі «Сяйво» (1913 р.), вказував на значні іï хиби - невиразність змальованих характерів, слабкість внутрішньої дії та мале психологічне іiї вмотивування, розгалуження дії за різними жанровими ознаками, навіть певна анекдотичність твору. «Аналіз фігур п’єси наводить на невідрадні думки. Характерів у п'єси сливе нема, за винятком однієї Христі <..> Картина мало відрадна, і це все в статичній стадії, без обопільних стосунків дієвих осіб. А, приведені в дію, фігури нагадують часами театр маріонеток. I, справді, в чому тут дія, насамперед внутрішня? В боротьбі дитинолюбства Романа 3 нелюбов'ю до жінки. Чи видно цю боротьбу? Нітрохи. Та на- 
віть і факт нелюбові теж вияснено мало, — більш тільки видко матеріалістичні до нього відносини жінки» $[19,249]$. Далі І. Стешенко зазначає про те, що навіть найкраще виписаний образ Христі, дружини Романа, має суттєві недоробки: «Ця Христя не показує себе з інтимного боку в стосунках з Романом. Чи вона любить його, чи ні. Про неї говориться, що вона не відпустить його від себе, - але 3 яких причин? 3 дії того не видко. $<\ldots>$ Що ж, справді, за відносини іiі до чоловіка, коли вона може розвести таку фізіологію з своїм актором? Таким чином, душевний бік ні їі, ні Романа, врешті не ясний, а на неясності збудувати драму неможливо» [19, 249].

Висновок критика - категоричне неприйняття п’єси «Натусь». На його думку, В. Винниченко взагалі дуже любить ризиковані та антиприродні сюжети: «Так Я намалював, так воно і в житті " $\epsilon$ або може бути”, - каже він нам і забува одно: мало щось сказати, треба доказати своїм малюнком. Але останнього нема... є тільки запас слів, уміло поставлених внішнє, та без внутрішнього потрібного змісту» $[19,249]$.

Але й драматург на гострий наступ критики не здавався, хоч і розуміючи слабкість характерів п’єси, в листі до свого приятеля і спонсора Є. Чикаленка дещо виправдовувався: «...це трагедія звичайних людей з їх вадами й гідностями, це не торжество добра над злом, а боротьба ріжних характерів, виховань, умов життя і т. д. А цілком добропорядних нема» [20].

Найцікавіше те, що новий твір В. Винниченка сприймався критиками по-різному. Так, авторитетний театрознавець Всеволод Чаговець, який завжди давав свою оцінку будь-яким творчим подіям, оцінював твір дуже високо: «Я повинен сказати, що п'єса написана пристрасно, що в ній, як у картинах Гойї, страшне і жахливе показане у поєднанні $з$ прекрасним, народженим справжнім талантом $<\ldots>$ Тут молодий вчений в обстановці своєї сім'ї, де дружина не знає інших запитів, окрім права бути дружиною і права вимагати від чоловіка грошей набагато більше, ніж він може дати зі своїх скромних заробітків» [21].

Головний герой п'єси Роман Возій губить свій талант через надто складні й нестерпні сімейні обставини; через них він змушений зректися особистого щастя й научного визнання. Одружившись на злій, міщанського виховання дівчині Христі, молодий учений щоразу має в сім'ї скандали, що найчастіше виникають через матеріальні нестатки та неправильне виховання матір'ю сина. Христя примушує свого чоловіка покинути заняття нау- кою і зайняти високооплачувану посаду секретаря в банку. Роман на ці пропозиції не погоджується. I хоча вже декілька разів намагається розлучитися 3 дружиною, але повертається у сім'ю знову і знову - $з$ глибокої любові до свого маленького синочка Натуся. Романів брат, Петро, з актором Чуй-Чуєнком задумали гру - закохати Романа в молоду й красиву актрису Дзижку, щоб тим полегшити його остаточне розлучення з Христею і дати підставу для звільнення Романа від сімейного терору. Більше того, актора Чуй-Чуєнка намовляють закрутити роман з Христею. Вдаючи закоханого, актор привертає іiі увагу до себе. Христя захоплюється Чуй-Чуєнком і приходить на побачення на квартиру до нього, де їх застукали свідки. У п’єсі, як і у виставі, цікаво розігруються сцени «театру у театрі». Зокрема епізод гри дійових осіб у піжмурки, що полегшує персонажам змогу зійтися в руслі задуманої гри.

Роман уже почав заходити до Дзижки попрацювати у спокійній обстановці, а згодом і зовсім переселився до її помешкання.

У третій і четвертій дії п'єси змінюються жанрово-стильові ознаки драматичного твору. Якщо у першій дії панувала атмосфера сатиричної комедії, то далі вона змінюється на абсолютно психологічну драму. Роман страшенно тужить за сином, настільки, що улюблене заняття наукою у прекрасних умовах його не захоплює. Тому він наважується написати додому листа, щоб син сам зробив вибір між матір'ю і батьком, а для того просить про зустріч із ним. Та на цю зустріч разом 3 дитиною приходить і Христя. Навчений матір'ю хлопець не визнає батька. У результаті Роман, не маючи сил далі боротися з розлукою із сином, переступає через сімейно-побутові злигодні і заради Натуся кидає Дзижку й іiі затишний куточок. Повертається додому в буденщину та атмосферу незворушного міщанства. Лагідної вдачі Роман не здатний протистояти сімейному пеклу, заради сина Натуся він готовий терпіти його і надалі. Романові не вдалося перебороти непорушної буденщини та закостенілого міщанства.

Основна інтрига п’єси «Натусь» розвивається на настирливій спробі Романового брата, Петра, який не може миритися з сімейним балаганом подружжя, вирвати дорогу йому людину, талановитого вченого з принизливих обставин сімейного знущання, з рук ненависного «бабила», коли «якась паршива, вульгарна баба... коверзує людиною».

Проте незважаючи на розбіжності критиків в оцінці літературно-художніх цінностей «Натуся», у театрі п’єсу прийняли із задоволенням, про 
що стверджує автор рецензії на постановку: «Вся п’єса "Натусь” ведеться в нервово-піднесених тонах, чому і захоплює глядачів з першої дії. Дбайливо обставлена, обмірковано з зовнішнього боку до найменших дрібниць і з боку виконання, вона дістала уважне до себе відношення i, я б сказав, любов, що видно було з кожного руху і з кожного сказаного слова» $[22,156]$.

Вистава «Натусь» у театрі М. Садовського у постановці режисера I. Мар'яненка, за визначенням театральної громадськості, мала середній успіх, але за одностайною оцінкою рецензентів, була цікавішою за саму п’єсу: «Трупа показала сімейне життя Романа Возія так повно і правдиво, що можна навіть виправдати ту штучну зав’язку п'єси: адже драма в цій сім’ї наростає з більшою і більшою силою, ворожий настрій до кінця у Возія все збільшується, розпанахана вдача жінки-міщанки все менше керується почуттям тактовності й терпимості, та все більше псує молодого Натуся, і коли в такі напружені відносини увіходить хоч легкий дотик сторонньої волі, то все мусить піти надзвичайно швидким темпом до трагічного кінця» [23].

У режисерській інтерпретації п'єса «Натусь» подавалась як родинно-психологічна драма, в якій вся увага зосереджувалась на акторському виконанні. Саме на цьому наголошував вже згаданий рецензент журналу «Сяйво»: «Актор ніби радів, що перед ним постала вимога показати себе в інтелігентних ролях, це ж так не часто трапляється в українському театрі - і доклав усіх сил, аби справитись із завданням найкраще» $[22,257]$. Атмосферу для вираження способу акторської взаємодії вже на початку вистави допомогла створити одна 3 перших авторських ремарок: «Христя й Роман говорять одночасно, але чути майже тільки Христю. Христя звертається до Романа, а Роман до Петра. Христя все більш і більш дратуючись, Роман все спокійніше й лагідніше».

Окрім режисерської праці, у виставі I. Мар'яненко ще виконував одну з головних ролей молодого вченого Романа Возія. У дослідженні сценічної історії п’єс В. Винниченка сучасний театрознавець П. Кравчук зауважує, що актор переконливо і з емоційною наповненістю розкривав тему батьківського почуття, яке прагнуло свого природного зростання, але силою обставин було задушене: «Наскрізним мотивом ролі була думка, що цей чоловік здатний відмовитись від свого щастя й повернутися до жахливої дружини-егоїстки та войовничої споживачки заради того, щоб не дозволити їй виховати сина у своєму дусі. Тому найбільше враження щирості й драматизму справила сцена розмови батька з сином» $[6,192]$.
Одначе рецензенти стверджували, що в інших сценах, де глядач мав дізнаватися про те, що Романа як лектора студенти «на руках носять», — саме цієї інтелектуальної сили характеру в актора не вистачало. Хоч глядач мав би розуміти, що міщанські уподобання дружини отримують лише тимчасову перемогу через експлуатацію батьківських почуттів, а також бачити, за що власне покохала його інша жінка - актриса Дзижка. Слід, щоб було зрозумілим, що Роман не зовсім затурканий, а що над ним влада сина, а не його бабила. Тому критик і підсумовував, що «Романа грав Мар'яненко. Грав добре, але грав» [23].

При текстовому знайомстві $з$ роллю дружини Романа Христі справляється враження однобічного, тенденційного змалювання постаті жінки-міщанки, з їі вульгарністю, матеріалізмом, егоїзмом, неморальністю та іншими численними гріхами. Шаблонність ¥ї реплік та міщанських вигуків, грубих вчинків та духовної злочинності дає змогу бачити в цьому образі сатиру, правда дещо малохудожню через свою різкість та однобічність. 3 перших фраз вистави глядач відчував безупинне збиткування дружини Христі-Ліницької над чоловіком, над його науковою працею, яка, на думку Христі, ніколи не принесе ій сподіваних статків: «3 жалуванням якихось сімсот-вісімсот рублів у рік? Я тобі кажу, що ти егоїст! < ..> Тобі пропонують шість тисяч на рік, і ти одмовляєшся під тим приводом, що твоє призначення наука. А ми повинні картоплю їсти..» Закономірно, що надалі про норови дружини Романа говорять, як про характер підлий, просто неможливий, одне слово, «бабило». Виконання ролі Христі талановитою артисткою Ліницькою дало такий живий, правдивий і переконливий образ, що у глядачів не виникало жодного сумніву щодо художності цього типу. Рецензент газети «Рада» стверджував, що «головною заслугою п. Ліницької - це темперамент жінки Возія; артистка дала цьому персонажеві стільки сили, нервів, пристрасті, провела роль в такому високому напруженому тоні, так жваво, яскраво і сильно, що весь час скупчувала на собі всю увагу глядачів». I далі: «В голосі, в тоні, в рухах чується сила перше всього, і це закрашує весь цей образ. Так, міщанка, вульгарна, груба, цинічна і безлабна, але вона своє знає, до своєї мети простує, упевнено, топчучи таку слабку людину, як Роман Возій» [24].

I хоч до цього часу Л. Ліницька ніколи не грала ролей лихих жінок та ще й з інтелігентного кола, — це не було іiї амплуа, — але для справжнього таланту не існувало жодних меж: лиха, хитра 
міщанська постать дружини Романа у відтворенні актриси знайшла прекрасного виразника. Наскрізною лінією персонажа Л. Ліницька протягувала грубу пробивну силу, що відчувалась в її постаті, в голосі і рухах, доводячи, що саме такі, як Христя, в суспільстві зиску мають неабияку вагу.

Очевидець вистави Василь Василько, тоді ще молодий актор, у спогадах про виконання ролі Христі Л. Ліницькою у щоденнику занотовує, що особливо яскраво артистка проводила початок першої дії, коли Христя-Ліницька невпинно підстрибувала, дуже швидко розмовляла і майже нікому не давала говорити. «Згадаймо, наприклад, “закулісну сцену" <...> Актриси на сцені нема, чути лише іiі голос сварки. Сварка за лаштунками - це своєрідний “концерт родинного щастя", та коли їй дають гроші - різкий перехід до улесливості. Дзвінкий, багатий барвами голос Ліницької-Христі доходив до вереску, а пізніше, коли давали гроші - відбувався несподіваний різкий перехід до улесливості. Голос Любові Павлівни давав можливість довести цю сцену до цілої звукової “симфонії. Враження залишалось незабутнє, і серед глядачів завжди була активна реакція на залаштункову сцену» $[25,106]$.

У грайливо-комедійній атмосфері відбувалась друга дія, кульмінація якої виявлялась у грі в піжмурки, де сценічно й переконливо виявлялися заплановані Петром взаємини персонажів. Найбільшу увагу привертала Христя Ліницької у щирій увазі до актора Чуй-Чуєнка, який відповідав господині дому закоханою небайдужістю. Гра у піжмурки була найцікавішою у Ліницької, 3 iï мальовничих пасажів загравання до Чуй-Чуєнка до глядачів зверталася лукава фізіономія Христі 3 ледь-ледь зав'язаним правим оком, а «бабило» уявляла себе граціозною дамочкою.

До кращих сцен рецензенти відносили i підфінальний епізод 3 тісними, але модними черевиками, після застукання парочки на гарячому, коли артистка нашвидкуруч їх намагалася взути; мімічно-пластична сценка артистки заслуговувала на концертний номер. Вона давала виконавиці прекрасний матеріал для розкриття всієї суті міщанства і пошлості. «Актриса не жаліла характерних фарб і пристосувань. Це була гостра сатира на обивательщину. Ця роль доводила, що в особі Ліницької театр має не лише героїню, а й першокласну характерну актрису» $[25,106]$.

До високого драматизму доходила у Ліницької і фінальна сцена, що набирала злих, різких і серйозних барв. Відчувалося, що Христя, втрачаючи Романа, на знак протесту може навіть вбити дитину і себе. Тому, зважаючи на серйозність становища, Чуй-Чуєнко пропонує всім вийти 3 гри. Згадуваний вже В. Василько писав: «Христя — от якою роллю ви можете посадити всіх, хто буде доказувати, що Ліницька - тільки героїня на драматичні ролі. Нi, героїні і помину нема, перед вами іменно «бабило», сварлива і уперта жінка, сама проза, якою тільки може бути жінка, і поряд тут же хитрість, двуличність і підлесливість» $[25,106]$.

На розвиток українського театру початку XX століття величезний вплив мало сценічне втілення творів В. Винниченка, вистави за його п'єсами були насичені персонажами найрізноманітніших класових, культурних і професійних психологічних типів. Звернення до першовтілення винниченківських п'єс у театрі М. Садовського вважалось чи не найголовнішою подією українського театрального процесу - відкриття нового напряму художньої творчості. Вистави «Брехня», «Натусь» i «Молода кров» виявлялися надзвичайно природними та сучасними, цікавими і потрібними як для акторів, так і глядачів. Були більш чи менш вдалими акторські роботи, але, і це головне, виставу грали не окремі виконавці, а добре зіграний не технічний, а емоційний ансамбль, де кожен творив у співвідношенні з партнером.

Режисерський досвід і вміння I. Мар'яненка у постановці п’єс В. Винниченка за участі найталановитіших виконавців, таких як сам I. Мар'яненко, Л. Ліницька, С. Паньківський, Ф. Левицький, М. Петляшенко, О. Корольчук, С. Рибчинський, О. Полянська, Я. Доля та інших у театрі М. Садовського надавали підступи до розгадки засад театральної умовності. Любов Ліницька як перша виконавиця жіночих ролей у винниченківських п'єсах демонструвала широкомасштабний талант, багату жанрово-стильову палітру акторської творчості і разом з тим сценічну культуру, вміння працювати не лише в класичних п'єсах, а й у творах новітньої драматургії. Вона була найталановитішою артисткою перехідного періоду українського театру. Сценічне ж освоєння принципів «нової драми» у iї виставах мало вплив на подальшу творчість режисерів, акторів, художників, критиків, а зрештою і на публіку, на ії призвичаєння до засад сценічного модернізму.

\section{Джерела та література}

1. Веселовська Г. Театральні перехрестя Києва 1900-1910-х pp. / Ганна Веселовська. - К. : Гнозіс, 2007. - 328 с.

2. Мороз Л.Драматургія Володимира Винниченка: ідейно-мистецьке експериментаторство на тлі «нової драми» кінця XIX - початку XX століть / Автореферат дис.... на здобуття наук. ст. доктора філологічних наук. - К., 1997. 
3. Панченко В. Магічний кристал / Володимир Панченко. Кіровоград : Народне слово, 1995. - 232 с.

4. Мороз З. Предисловие // Марьяненко И. Прошлое украинского театра. Воспоминания / 3. Мороз. - М. : Искусство. - 1954. - $252 \mathrm{c}$.

5. Мар'яненко І. Сцена, актори, ролі / Іван Мар'яненко. К. : Мистецтво. - 1964. — 292 с.

6. Кравчук П. Режисерські пошуки I. Мар'яненка у виставах за п'єсами В. Винниченка // Мистецтвознавство України. - К. -2001.

7. Смолич Ю.Нові п'єси В.Винниченка // Критика. 1929. - №4.

8. Онишкевич Л. «Пророк» - остання драма Володимира Винниченка // Слово. - Едмонтон, Альберт, Канада. 1973. - №5.

9. Гуменюк В.Сила краси. Проблеми поетики драматургії Володимира Винниченка / Віктор Гуменюк. - Сімферополь : міська друкарня, 2001. - 338 с.

10. Кисіль О. Український театр / Олександр Кисіль. - К. : Книгоспілка. - 1925. - 178 с.

11. Вороний М. Театр і драма / Микола Вороний. - К. : Мистецтво. - 1989. - 408 с.

12. Вечерницький А. /Олександр Кузьминський/. «Брехня» В. Винниченка // Рада. - 1911. - 22 січня.

13. Alienus /Павло Богацький/. Нова драма (3 приводу постановки «Брехні» В. Винниченка трупою М. Садовського) // Українська хата. - К., 1911. — №3.

14. Чаговец В. «Брехня» // Киевская мысль. - 1911. — 22 января.

15. Вечерницький А. /Олександр Кузьминський/. «Брехня» В. Винниченка // Рада. — 1911. — 4 лютого.

16. Вечерницький А. Трупа М. К. Садовського (сезон 19111912 року) // Рада. - 1912. — 1 травня.

17. D.C.Спектакли украинской труппы // Одесский листок. - 1915. - 22 октября.

18. Залеська-Онишкевич Л. Антологія модерної української драми. Паралельний том до Антології модерної укр. драми. - К., 1998.

19. Стешенко І. «Натусь» // Сяйво. - 1913. - №10-12.

20. Винниченко В. Лист до Є. Чикаленка від 24 серпня 1912 року // Відділ рукописів ЦНБ ім. В.Вернадського АН України. — Фонд 293.

21. Чаговец В. Театр народного дома // Киевская мысль. 1913. - 15 октября.

22. Benevolus /Василь Василько/. «Натусь», п’єса В. Винниченка // Сяйво. - 1913. - №10-12.

23. Василько А. /Андрій Ніковський/. «Натусь», п’єса на 4 дії В. Винниченка // Рада. — 1913. - 28 жовтня.

24. Василько А. / Андрій Ніковський/ «Натусь» // Рада. 1913. - 15 жовтня.

25. Василько В. Щоденник // Архів-музей літератури і мистецтва України. - Ф. 653. - Спр. 189. - Оп. 2. - С. 106.

\section{References}

1. Veselovska, H. Teatralni perekhrestia Kyieva 1900-1910-kh rr. / Hanna Veselovska. — K. : Hnozis, 2007. — 328 s.
2. Moroz, L. Dramaturhiia Volodymyra Vynnychenka: ideinomystetske eksperymentatorstvo na tli «novoi dramy» kintsia $\mathrm{KhIKh}$ - pochatku KhKh stolit / Avtoreferat dys.... na zdobuttia nauk. st. doktora filolohichnykh nauk. - K., 1997.

3. Panchenko, V.Mahichnyi krystal / Volodymyr Panchenko. Kirovohrad : Narodne slovo, 1995. — $232 \mathrm{~s}$.

4. Moroz, Z. Predislovie // Maryanenko I. Proshloe ukrainskogo teatra. Vospominaniya / Z. Moroz. - M. : Iskusstvo. 1954. - $252 \mathrm{~s}$.

5. Marianenko, I. Stsena, aktory, roli / Ivan Marianenko. - K. : Mystetstvo. - 1964. - $292 \mathrm{~s}$.

6. Kravchuk, P. Rezhyserski poshuky I. Marianenka u vystavakh za piesamy V. Vynnychenka // Mystetstvoznavstvo Ukrainy. - K. - 2001.

7. Smolych, Yu. Novi piesy V. Vynnychenka // Krytyka. 1929. — № 4.

8. Onyshkevych, L. «Prorok» — ostannia drama Volodymyra Vynnychenka // Slovo. — Edmonton, Albert, Kanada. 1973. 一 № 5 .

9. Humeniuk, V.Syla krasy. Problemy poetyky dramaturhii Volodymyra Vynnychenka / Viktor Humeniuk. Simferopol : miska drukarnia, 2001. - $338 \mathrm{~s}$.

10. nyhospilka. - 1925. - $178 \mathrm{~s}$.

11. Voronyi, M. Teatr i drama / Mykola Voronyi. - K. : Mystetstvo. - 1989. - $408 \mathrm{~s}$.

12. Vechernytskyi, A. /Oleksandr Kuzmynskyi/. «Brekhnia» V. Vynnychenka // Rada. — 1911. — 22 sichnia.

13. Alienus /Pavlo Bohatskyi/. Nova drama ( $Z$ pryvodu postanovky «Brekhni» V.Vynnychenka trupoiu M. Sadovskoho) // Ukrainska khata. - K., 1911. — № 3.

14. Chagovets, V. «Brehnya» // Kievskaya myisl. — 1911. — 22 yanvarya.

15. Vechernytskyi, A. /Oleksandr Kuzmynskyi/. «Brekhnia» V. Vynnychenka // Rada. - 1911. - 4 liutoho.

16. Vechernytskyi, A. Trupa M. K. Sadovskoho (sezon 19111912 roku) // Rada. - 1912. - 1 travnia. Vechernytskyi A. Trupa M. K. Sadovskoho (sezon 1911-1912 roku) // Rada. - 1912. - 1 travnia.

17. D.C. Spektakli ukrainskoy truppyi // Odesskiy listok. 1915. - 22 oktyabrya.

18. Zaleska-Onyshkevych, L.Antolohiia modernoi ukrainskoi dramy. Paralelnyi tom do Antolohii modernoi ukr. dramy. K., 1998.

19. Steshenko, I. «Natus» // Siaivo. — 1913. — №10-12.

20. Vynnychenko, V. Lyst do Ye. Chykalenka vid 24 serpnia 1912 roku // Viddil rukopysiv TsNB im. V. Vernadskoho AN Ukrainy. - Fond 293.

21. Chagovets, V. Teatr narodnogo doma // Kievskaya myisl. 1913. - 15 oktyabrya.

22. Benevolus /Vasyl Vasylko/. «Natus» piesa, V. Vynnychenka // Siaivo. - 1913. - №10-12.

23. Vasylko, A. /Andrii Nikovskyi/. «Natus», piesa na 4 dii V. Vynnychenka // Rada. — 1913. — 28 zhovtnia.

24. Vasylko, A. / Andrii Nikovskyi/ «Natus» // Rada. — 1913. 15 zhovtnia.

25. Vasylko, V. Shchodennyk // Arkhiv-muzei literatury i mystetstva Ukrainy. - F. 653. - Spr. 189. - Op. 2. — S. 106. 